\title{
Inherited multiple meningiomas: A clinical, pathological and cytogenetic study of an affected family
}

\author{
RDE BATTERSBY ${ }^{*}$ JW IRONSIDE, $\dagger$ EL MALTBY \\ From the Departments of Neurosurgery* and Neuropathology $\dagger$ Royal Hallamshire Hospital, and the Centre for \\ Human Genetics, $\ddagger$ Sheffield, UK
}

SUMMARY The clinical features of a family with inherited multiple meningiomas as the major manifestation of neurofibromatosis are presented. The value of noninvasive radiological screening investigations is emphasised. The results of cytogenetic and pathological studies on the family are presented and discussed with a review of the relevant literature.

Multiple meningiomas commonly occur in the central form of neurofibromatosis ${ }^{12}$ and are often associated with bilateral acoustic neuromas. ${ }^{3-5}$ Although there are a few reports of familial meningiomas occurring in the absence of additional features of neurofibromatosis ${ }^{6-12}$ the evidence for inheritance of meningiomas alone is inconclusive. We report a family with multiple meningiomas associated with minor stigmata of neurofibromatosis and present a clinical and cytogenetic study of the affected kindred together with the results of chromosome analysis and steroid hormone receptor investigations on surgically resected neoplasms.

\section{Case histories}

The family pedigree is illustrated in fig 1 . The propositus (III-1) was referred for the investigation of abnormal intracranial calcification. The clinical history, examination and radiological findings are summarised in table 1 and figure 2 . The patient was found to have neurofibromatosis of predominantly central type with multiple intracranial lesions, peripheral lesions and suspected intraspinal lesions. She had progressive visual impairment with evidence of raised intracranial pressure and was advised to have a large subfrontal intracranial lesion excised. At craniotomy a dural plaque of tumour tissue, with several nodules indenting the surface of the brain, was found to extend well beyond the margins of the exposure. Several nodules and a small tumour on the sphenoidal wing were removed prior to removal of the large

Address for reprint requests: Dr JW Ironside, Department of Neuropathology, Royal Hallamshire Hospital, Glossop Road, Sheffield S10 2JF, UK.

Received 3 May 1985 and in revised form 7 August 1985 Accepted 8 August 1985 subfrontal tumour which was eroding the jugum sphenoidale. The patient improved postoperatively with loss of headache and some restoration of vision.

Neurofibromatosis had previously neither been diagnosed nor even suspected in this family, and subsequently several members requested screening examinations. The surviving members of the first and second generations, now elderly but in good health and without apparent neurological impairment, did not request screening. The deceased member of the first generation had died at the age of 60 years after a myocardial infarction. No other information on this patient is available.

Patient II-2 died in 1955 aged 27 years of "brain tumour" and a post mortem examination of the nervous system found multiple intracranial lesions and a single intraspinal cervical lesion. The presence of peripheral lesions is unknown as no additional clinical details are available.

Clinical and radiological studies were carried out on other members of the third and fourth generations of the family (table 2 and fig 3). Patient III-2 has multiple intracranial and peripheral lesions. Patient IV-1 has multiple intrancranial lesions. All of the male patients screened were asymptomatic and without neurological impairment. However, one appar-

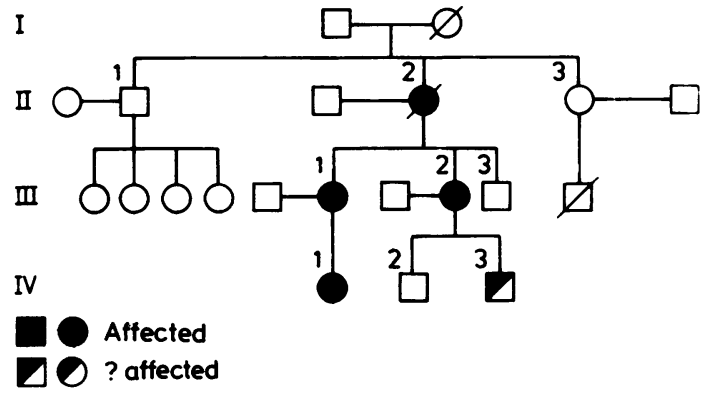

Fig 1 Family pedigree. 
Table 1 Clinical and radiological findings in patient III-1 with minimal cutaneous manifestations of neurofibromatosis

\begin{tabular}{|c|c|c|c|}
\hline Case & Clinical presentation & Examination & Radiological findings \\
\hline $\begin{array}{l}\text { III-1 } \\
\text { Female } 36 \text { years }\end{array}$ & $\begin{array}{l}\text { Progressive visual impairment, } \\
\text { deteriorating memory and sense } \\
\text { of smell, and increasing headaches } \\
\text { for } 1 \text { year. Persistent right } \\
\text { conjunctivitis for } 3 \text { mths } \\
\text { Past medical history: See Table } 3\end{array}$ & $\begin{array}{l}4 \text { sessile thoracic fibromata mollusca } \\
5 \times 2 \mathrm{~cm} \text { neurofibroma right radial } \\
\text { nerve. } \\
\text { Multiple tendon transpostions at } \\
\text { right wrist } \\
\text { Impaired short term memory } \\
\text { Bilateral hyposmia } \\
\text { Right papilloedema: acuity } 6 / 12 \\
\text { Left cataract: light perception only } \\
\text { Right medial and inferior rectus } \\
\text { muscle palsy } \\
\text { Left complete ophthalmoplegia } \\
\text { Right trigeminal sensory impairment } \\
\text { (all divisions) } \\
\text { Bilateral sensorineural deafness: } \\
\text { Right } 80 \text { db, Left } 50 \text { db } \\
\text { Caloric responses absent bilaterally } \\
\text { Bilateral spinal accessory nerve palsy } \\
\text { Right hypoglossal nerve palsy } \\
\text { Atrophy and weakness of supraspinati, } \\
\text { right serratus anterior, extensors of } \\
\text { right forearm, right intrinsic hand } \\
\text { muscles and left deltoid } \\
\text { Sensory impairment: right C4-C8, } \\
\text { right D6-D11, left axillary nerve } \\
\text { Right triceps and bilateral ankle } \\
\text { stretch reflexes absent } \\
\text { Abdominal reflexes absent } \\
\text { Plantar responses flexor }\end{array}$ & $\begin{array}{l}\text { Skull radiograph: extensive } \\
\text { calcification left choroid plexus; } \\
\text { subfrontal midline calcification; } \\
\text { scattered posterior fossa calcification } \\
\text { CT scan (EMI 1010) subfrontal, } \\
\text { intraventricular and multiple } \\
\text { convexity calcified contrast- } \\
\text { enhancing lesions } \\
\text { Contrast-enhancing lesions right } \\
\text { cerebellopontine angle, also } \\
\text { intracerebellar calcification } \\
\text { Cerebral angiography: multiple } \\
\text { intracranial meningiomas. } \\
\text { Continuous extrinsic tumour growth } \\
\text { over left cerebral hemisphere up to } \\
0 \cdot 5 \text { cm in thickness, with multiple } \\
\text { tumourous nodules bulging inwards } \\
\text { up to } 2 \text { cm from cranial vault (fig } 2 \text { ) }\end{array}$ \\
\hline
\end{tabular}

ently unaffected male (IV-2) has café-au-lait spots and patient IV-3 has abnormal tentorial calcification. A similar pattern of neurological impairment was noted in patients III-1, III-2, and IV-1 (table 3). An erroneous diagnosis of peroneal muscular atrophy was made in patient III-2 at the age of 6 years and subsequent development of neurological signs in patient III-1 was attributed to a familial form of muscular dystrophy. Cytogenetic studies were performed on all of the patients examined and the family has received genetic counselling.

\section{Materials and methods}

\section{Histopathology}

The brain and meninges removed at necropsy from patient II- 2 and the two intracranial neoplasms removed surgically from patient III-1 were fixed in a $10 \%$ solution of formol saline (pH 7.0). Tissue for histological analysis was processed routinely into paraffin wax from which sections were cut at $5 \mu \mathrm{m}$ and stained by conventional histological techniques.

\section{Steroid Hormone Receptor Studies}

Small portions of fresh tissue from the neoplasms removed at surgery from patient III-1 were snap frozen and stored at $-70^{\circ} \mathrm{C}$ for a period of two weeks. Cryostat sections were cut for histological analysis and for assay of oestrogen and progesterone receptors in cytosols from the tissue sections using an isoelectric focussing technique. ${ }^{1314}$ The ligands used were ${ }^{3} \mathrm{H}$-Oestradiol (Amersham International TRK 322) and ${ }^{3}$ H-ORG2058 (Amersham International TRK 629).

\section{Cytogenetics}

Peripheral blood samples were obtained from patients III-1, III-2, III-3, IV-1, IV-2 and IV-3. Lymphocytes were cultured for 72 hours in medium TC-199 (Gibco) with $20 \%$ fetal calf serum. The cultures were then treated with methotrexate followed by thymidine prior to metaphase arrest with colchicine in order to obtain prometaphase-type chromosomes. ${ }^{15}$ Karyotyping was performed following trypsin G-banding of metaphase preparations. ${ }^{16}$ The two meningio-

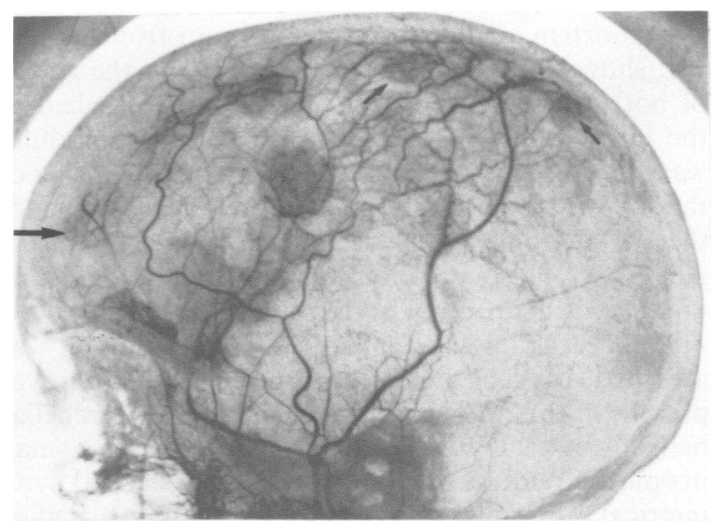

Fig 2 Left carotid angiography (2 superimposed subtraction studies) in patient III-1 showing multiple intracranial meningiomas. At least 10 lesions are seen; 3 of the smallest are arrowed. 
Table 2 Clinical and radiological findings in five members of the family who requested screening investigations. (Note the minimal cutaneous stigmata of neurofibromatosis in the affected patients)

\begin{tabular}{|c|c|c|c|}
\hline Case & Clinical presentation & Examination & Radiological findings \\
\hline $\begin{array}{l}\text { III-2 } \\
\text { Female } 33 \text { yr }\end{array}$ & $\begin{array}{l}\text { Weakness right ankle } 27 \text { y } \\
\text { Right deafness } 3 \text { y } \\
\text { Past medical history: See table } 3\end{array}$ & $\begin{array}{l}1 \text { cafe-au-lait spot right calf } \\
5 \text { sessile thoracic fibromata mollusca } \\
\text { Left external strabismus, } 10^{\circ} \\
\text { restriction of medial and lateral gaze } \\
\text { Left retinal detachment } \\
\text { Right sensorineural deafness } \\
\text { Atrophy extensor compartment right leg } \\
\text { Weak dorsiflexion/eversion right ankle } \\
\text { Hyperaesthesia lateral border right foot } \\
\text { Partial surgical fusion right ankle }\end{array}$ & $\begin{array}{l}\text { Conray-enhanced CT scan: right cere- } \\
\text { bello-pontine angle lesion } \\
\text { Calcification right trigone } \\
\text { Left parasagittal and ?left subfrontal } \\
\text { lesions }\end{array}$ \\
\hline $\begin{array}{l}\text { III-3 } \\
\text { Male } 31 \text { y }\end{array}$ & Asymptomatic & Normal & Conray-enhanced CT scan: normal \\
\hline $\begin{array}{l}\text { IV-1 } \\
\text { Female } 17 \text { y }\end{array}$ & $\begin{array}{l}\text { Deafness right } 2 \text { y } \\
\downarrow \text { Vision left eye } 10 \text { y }\end{array}$ & $\begin{array}{l}\text { Café-au-lait spots left arm, right } \\
\text { thigh } \\
\text { Bilateral vertical and horizontal } \\
\text { nystagmus } \\
\text { Left visual acuity } 6 / 36 \\
\text { Right sensorineural deafness }\end{array}$ & $\begin{array}{l}\text { Conray-enhanced CT scan: high density } \\
\text { (1400 EMI units) lesions in region of } \\
\text { body of right lateral ventricle and } \\
\text { within third ventricle. Presumed } \\
\text { tumours of meningeal origin (fig } 3 \text { ). } \\
\text { Small cerebellopontine angle lesions } \\
\text { not excluded }\end{array}$ \\
\hline $\begin{array}{l}\text { IV-2 } \\
\text { Male } 8 \text { y }\end{array}$ & Asymptomatic & $\begin{array}{l}3 \text { café-au-lait spots (interscapular, } \\
\text { lumbar) }\end{array}$ & Conray-enhanced CT scan: normal \\
\hline $\begin{array}{l}\text { IV-3 } \\
\text { Male } 5 \text { y }\end{array}$ & Asymptomatic & Normal & $\begin{array}{l}\text { Conray-enhanced CT scan: right tentorial } \\
\text { calcification } \\
\text { Left temporal lobe tip agenesis }\end{array}$ \\
\hline
\end{tabular}

mas excised from patient III-1 were cultured in medium TC199 with $20 \%$ fetal calf serum and chromosomes were examined after the second and third passages. Suspension harvests were studied using the trypsin G-banding technique.

\section{Results}

\section{Histopathology}

Post mortem examination of the brain from patient II-2 showed numerous depressed areas in the cortex of both hemispheres formed by nodules attached to the inner surface of the dura (fig 4). These nodules were especially numerous on the falx on either side of the superior longitudinal sinus. There were large nodules of tumour attached to both the VIII cranial nerves. A large depression was present in the midline on the under surface of both frontal lobes between the olfactory tract in which a large nodule of tumour was attached to the dura. A further depression was present in the posterior aspect of the right cerebellar hemisphere which had also been occupied by a small neoplastic nodule. Section of the brain showed symmetrical ventricular dilatation with two small calcified nodules present in the ventricles adjacent to the foramina of Monro. The cortex, white matter, basal ganglia, brain stem and cerebellum showed no gross abnormalities. Histological examination of the VIII

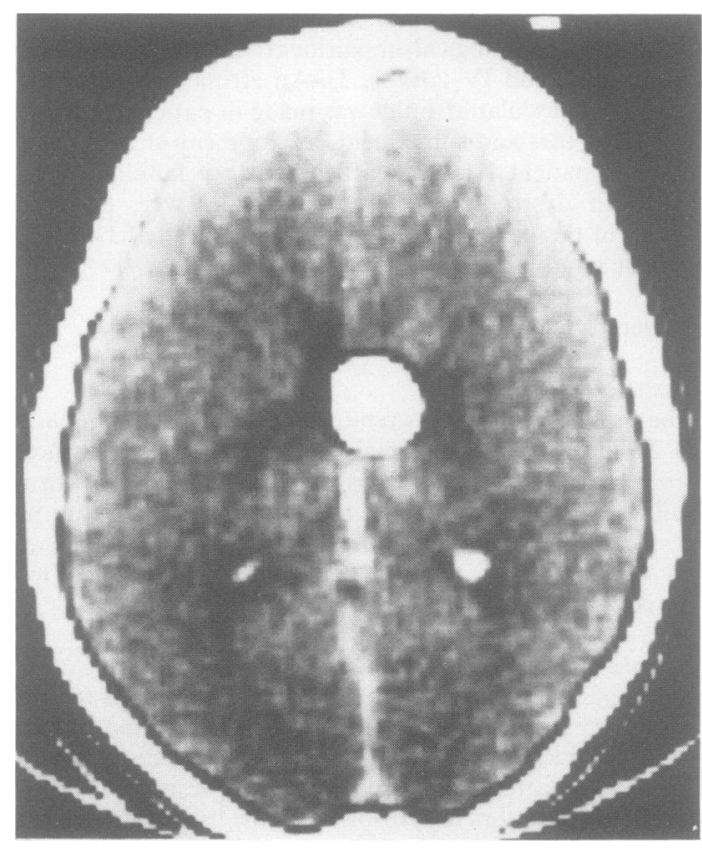

Fig 3 Conray-enhanced CT scan of patient IV-I showing high density lesions in and around the third ventricle. 
Table 3 Pattern of neurological impairment in 3 affected female members of the family illustrating the phenotypic similarity

\begin{tabular}{llllll}
\hline Case & $\begin{array}{l}\text { Age } \\
\text { (yrs) }\end{array}$ & Ocular impairment & Trigeminal nerve impairment & Auditory nerve impairment & Peripheral nerve palsies \\
\hline III-1 & 36 & $\begin{array}{l}\text { Left external strabismus (1) } \\
\text { Vision left eye (cataract) } \\
(18) \\
\text { Right external strabismus } \\
(26)\end{array}$ & $\begin{array}{l}\text { Right trigeminal neuralgia } \\
\left(\mathrm{V}_{1}\right)(34)\end{array}$ & $\begin{array}{c}\text { Right sensorineural deaf- } \\
\text { ness (31) }\end{array}$ & $\begin{array}{c}\text { Right posterior inter- } \\
\text { osseus nerve (21) } \\
\text { Right long thoracic } \\
\text { nerve (28) }\end{array}$ \\
III-2 & 33 & $\begin{array}{l}\text { Left external strabismus (1) } \\
\downarrow \text { Vision left eye (retinal } \\
\text { detachment) (3) }\end{array}$ & Left conjunctivitis (31) & $\begin{array}{c}\text { Right sensorineural deaf- } \\
\text { ness (30) }\end{array}$ & Right peroneal nerve (6) \\
IV-1 & 17 & $\begin{array}{l}\text { Left external strabismus (4) } \\
\downarrow \text { Vision left eye (5) }\end{array}$ & $\begin{array}{c}\text { Right sensorineural deaf- } \\
\text { ness (2) }\end{array}$ & \\
\hline
\end{tabular}

(n) = age at which disability first noticed.

cranial nerve tumours showed the appearances of acoustic neuromas. The other neoplastic nodules were meningiomas of transitional type except for the intraventricular lesions which were psammomatous. Histological examination of the large subfrontal tumour from patient III-1 showed a transitional meningioma and the small tumour on the sphenoidal wing was a psammomatous meningioma. Both of the neoplasms were oestrogen receptor negative. The transitional meningioma was progesterone receptor negative but the psammomatous meningioma was progesterone receptor positive $(15 \mathrm{fmol} / \mathrm{mg}$ cytosol protein).

\section{Cytogenetics}

Examination of prometaphase chromosome spreads from peripheral lymphocytes showed no structural abnormalities in any of the patients. However, patient III-3 had two hyperdiploid cells amongst the normal counts; both of these contained additional No 22 chromosomes. Chromosome preparations from the psammomatous meningioma showed a $45, \mathrm{XX}-22$ karyotype but the transitional meningioma had

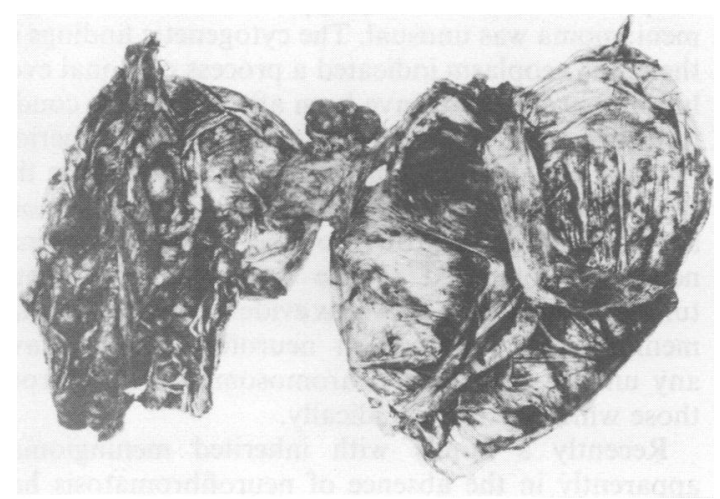

Fig 4 Multiple meningiomas are present on the dura from patient II-2. several cell lines with extreme numerical and structural abberations (fig 5). Cell lines with 41, 42 and 43 chromosomes were seen and occasional polyploid cells with 80-82 chromosomes were present. Missing chromosomes in the above lines included 1, 2, 3, 4, 6, $8,9,15,19$ and 22 . They were replaced by a series of derivative or "marker" chromosomes. The No 22 chromosome was not obviously represented in a derivative chromosome. Two of the marker chromosomes involving recognisable areas of chromosome No 3 and chromosome No 9 were always present. The presence of other markers was variable in different cell lines. There were also numerous breaks, gaps, fragments and occasional rings in the metaphases examined.

\section{Discussion}

The family described in this report has a predominantly central form of neurofibromatosis in which female members are most affected and cutaneous manifestations of the disease are minimal. One young asymptomatic male (IV-3) with possible central involvement has no detectable cutaneous stigmata and one other male (IV-2) has minimal cutaneous stigmata. Minimal manifestations of cutaneous involvement in patients with central forms of neurofibromatosis with multiple intracranial tumours are well documented and it has been suggested that the same may apply to those with solitary spinal tumours. ${ }^{17}$ Cutaneous manifestations may easily be overlooked, leading to an erroneous diagnosis as occurred initially in this family. In addition, unless noninvasive radiological investigations are performed, the degree of central involvement in asymptomatic patients in families with neurofibromatosis will remain unknown.

It appears likely, as suggested by Delleman et al ${ }^{18}$ that inheritance of meningiomas alone does not occur and that cases reported as such probably represent one extreme of the spectrum of neurofibromatosis. 


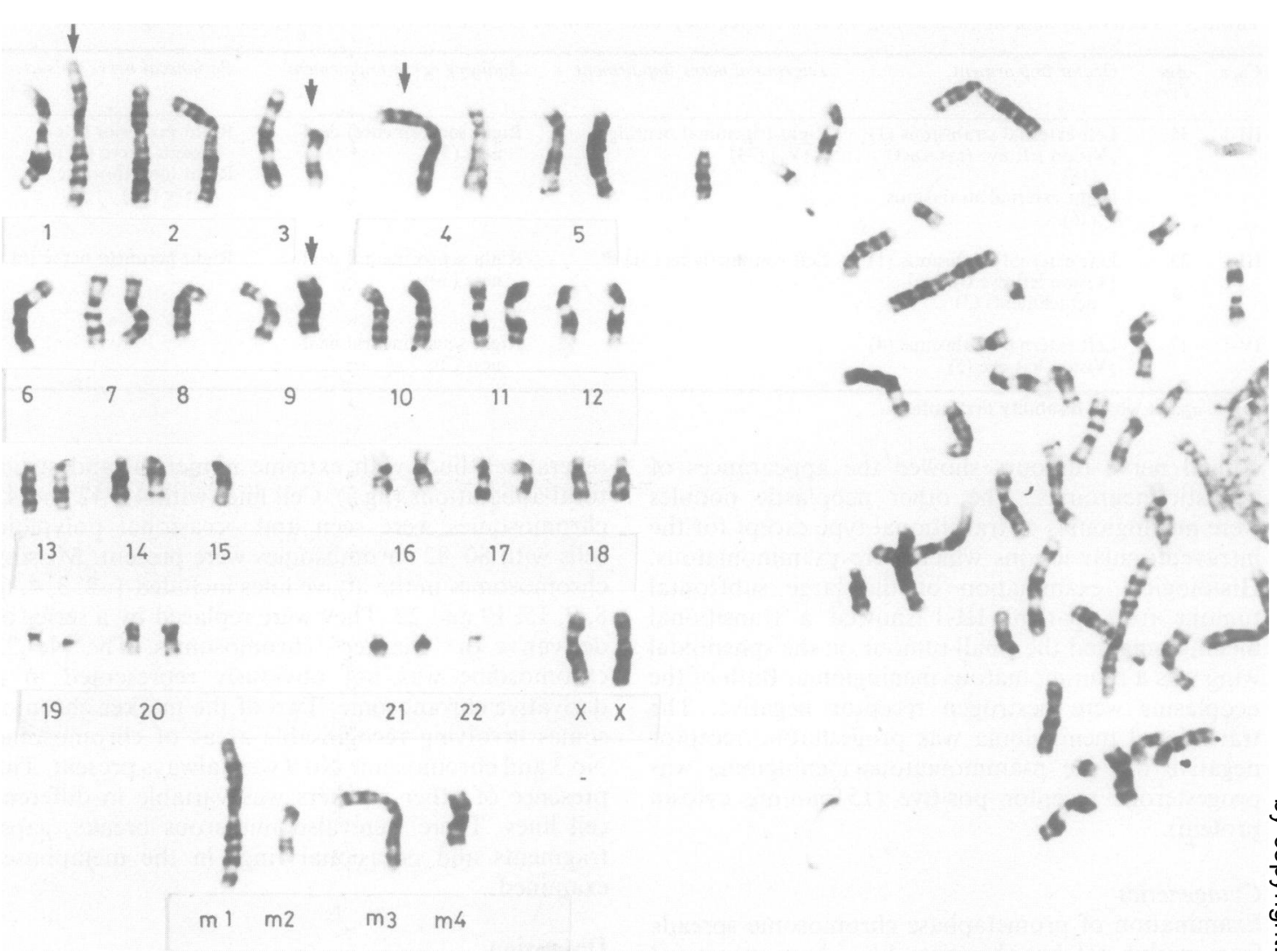

Fig 5 Metaphase cell and karyotype from the cultured transitional meningioma from patient III-1 showing structural rearrangements. 41 chromosomes are present; numbers 1, 3, 4, 6, 8, 9, 15 and 22 are missing and 4 derivative chromosomes. arrowed in the karyotype and labelled M1-M4 are present.

Occult central forms of this disorder might explain the occasional irregular dominant inheritance seen in some pedigrees where one "skipped" generation appears unaffected. The remarkably similar pattern of disease involvement among the affected members of this family is unusual. In the series reported by Crow et al ${ }^{19}$ marked phenotypic variation was seen within families. The reasons for the predominance of females among affected members of this family are unclear. In the absence of neurofibromatosis, it is known that meningiomas occur more frequently in females $^{20}$ but no data are available on the relative incidence of meningiomas in male and female patients with neurofibromatosis.

It has been suggested for several years that the evolution of the chromosome karyotype in meningiomas is characterised by the loss of deletion of chromosome No $22 .{ }^{21}$ The loss of further chromosomes leading to hypodiploidy has also been reported. ${ }^{22}$ The karyo- type of the psammomatous meningioma from patient III-1 may be considered as typical for this type of neoplasm, but the karyotype of the transitional meningioma was unusual. The cytogenetic findings in the latter neoplasm indicated a process of clonal evolution, but this may have been affected by the conditions of cell culture even for the relatively short period in vitro. The different chromosome findings from the two excised meningiomas may simply reflect the more advanced stage of growth of the larger transitional neoplasm compared to the small psammomatous tumour. There is no previous evidence to suggest that meningiomas occurring in neurofibromatosis have any unique or different chromosomal findings from those which occur sporadically.

Recently a family with inherited meningiomas apparently in the absence of neurofibromatosis has been reported with a Robertsonian translocation $T(14 ; 22)(14 q$ ter $\rightarrow C E N \rightarrow 22 q$ ter $)$ in peripheral 
blood leucocytes. ${ }^{12}$ This abnormality was detected in both affected and nonaffected members. A variant of the c-SIS oncogene was detected in peripheral blood leucocyte DNA in two affected and one unaffected family members, and the authors have suggested that this oncogene may be associated with the development of meningiomas in that particular family. With these findings in mind the somatic karyotypes of the patients in the third and fourth generations in this family were carefully studied. No structural chromosomal abnormalities were detected but the presence of hyperdiploid cells from patient III-3, involving additional No 22 chromosomes, may be an indication of some predisposition to mitotic nondisjunction.

The findings at necropsy in patient II-2 were typical of central neurofibromatosis with multiple meningiomas, and are very similar to the radiological and surgical findings in her daughter (patient III-1). There was also a strong resemblance to one of the four cases (Case 2) of multiple meningiomas described by Waga et $\mathrm{al}^{23}$ in whom no stigmata of neurofibromatosis were found. The diagnosis of neurofibromatosis was also not suspected initially in patient II-2, and was only made many years after death when her children manifested stigmata of the disease. Meningiomas occurring in patients with neurofibromatosis do not possess any distinctive histological features ${ }^{20}$ and the different microscopic findings in the neoplasms removed from patient III-1 may be a reflection of differential growth rates since heavily calcified psammomatous meningiomas are thought to grow more slowly than other types. ${ }^{20}$ This suggestion is in accordance with the cytogenetic findings in these two neoplasms.

There has been much recent interest in the presence of steroid hormone receptors in human meningiomas ${ }^{142425}$ and it has been suggested that hormonal manipulation may be of value in the management of patients with progesterone receptor positive meningiomas. ${ }^{26}$ While this suggestion is as yet speculative such treatment might be of value to patients with progesterone receptor positive meningiomas in this and other similar families where the presence of multiple neoplasms renders surgical management difficult.

We are grateful to Mr J Jakubowski, Department of Neurosurgery, for advice regarding patients under his care, to Dr T Powell, Department of Radiology, for performing the radiological screening investigations, and to Dr WR Timperley, Department of Neuropathology, all of the Royal Hallamshire Hospital, Sheffield for permission to publish the post mortem findings on patient II-2 (necropsy performed by the late Dr L Wolman). Thanks are due to Miss VJM Dangerfield and to Mr A Buxton for technical assis- tance, and to Mrs P Kirk for typing the manuscript. Financial support from the Trent Regional Health Authority Locally Organised NHS Research Fund (Account Number 039) is gratefully acknowledged.

\section{References}

${ }^{1}$ Hosoi K. Meningiomas (with special reference to the multiple intracranial type). Am J Pathol 1930;6:245-60.

${ }^{2}$ Cushing H, Eisenhardt L. Meningiomas: Their Classification, Regional Behavior, Life History and Surgical End Results. Springfield, Illinois: Charles C Thomas, 1938.

${ }^{3}$ Cushing H. Tumours of the Nervus Acusticus and the Syndrome of the Cerebellopontine Angle. Philadelphia: WB Saunders, 1917.

${ }^{4}$ Davidoff LM, Martin J. Hereditary combined neurinomas and meningiomas. $J$ Neurosurg 1955;12:375-84.

${ }^{5}$ Rovine BW, Mulford EH. Bilateral acoustic neurinomas with multiple meningiomas. Neurology (Minneap) 1960;10:323-4.

${ }^{6}$ Gaist G, Piazza G. Meningiomas in two members of the same family (with no evidence of neurofibromatosis). J Neurosurg 1959;16:110-3.

${ }^{7}$ Sahar A. Familial occurrence of meningiomas. $J \mathrm{Neu}$ rosurg 1965;23:444-9.

${ }^{8}$ Joynt RJ, Perret CE. Meningiomas in a mother and daughter. Cases without evidence of neurofibromatosis. Neurology (Minneap) 1961;11:164-5.

${ }^{9}$ Pamphlett R, MacKenzie R. Familial occurrence of meningioma. Clin Exp Neurol 1981;18:169-73.

${ }^{10}$ Memon MY. Multiple and familial meningiomas without evidence of neurofibromatosis. Neurosurgery 1980;7: 262-4.

${ }^{11}$ Sedzimir CB, Fraser AK, Roberts JR. Cranial and spinal meningiomas in a pair of identical twin boys. $J$ Neurol Neurosurg Psychiatry 1973;36:368-76.

12 Bolger GB, Stamberg J, Kirsch IL, Hollis GF, Schwartz DF, Thomas GH. Chromosome translocation $t(14 ; 22)$ and oncogene (c-SIS) variant in a pedigree with familial meningioma. $N$ Engl J Med 1985;312:564-7.

${ }^{13}$ Underwood JCE, Dangerfield VJM, Parsons MA. Oestrogen receptor assay of cryostat sections of human breast carcinomas with simultaneous quantitative histology. J Clin Pathol 1983;36:399-405.

${ }^{14}$ Ironside JW, Battersby RDE, Dangerfield VJM, Parsons MA, Timperley WR, Underwood JCE. Oestrogen and progesterone receptors in human meningiomas: measurement of specific receptors by an isoelectric focusing technique. J Pathol 1985;145:75a.

${ }^{15}$ Barnes ICS, Maltby EL. Evaluation of prometaphase chromosome analysis as a routine diagnostic method. Clin Cytogenet Bull 1983;1:78-84.

${ }^{16}$ Seabright M. A rapid banding technique for human chromosomes. Lancet 1971;ii:971-2.

${ }^{17}$ Canale DJ, Bebin J. Von Recklinghausen's disease of the nervous system. In: Vinken PJ and Bruyn GW, eds. Handbook of Clinical Neurology. Amsterdam: North Holland Publ Co 1972;14:151-5.

${ }^{18}$ Delleman JW, De Jong JGY, Bleeker GM. Meningiomas in five members of a family over two generations, in one 
member simultaneously with acoustic neuromas. Neurology (Minneap) 1978;28:567-70.

${ }^{19}$ Crowe FW, Schull WJ, Neill JW. A Clinical, Pathological and Genetic Study of Multiple Neurofibromatosis. Springfield, Illinois: Charles C Thomas, 1956.

${ }^{20}$ Russell DS, Rubinstein LJ. Tumours of the meninges and related tissues. In: Pathology of Tumours of the Nervous System, 4th edn. London: Edward Arnold 1977: 65-100.

${ }^{21}$ Zankl H, Zang KD. Cytological and cytogenetical studies on brain tumours IV. Identification of the missing $G$ chromosome in human meningiomas as No 22 by fluorescence technique. Hum Genet 1972;14:167-9.

${ }^{22}$ Mark J. The chromosomal findings in seven human meningiomas and one neurosarcoma. Acta Pathol
Microbiol Scand 1972;80:61-70.

${ }^{23}$ Waga S, Matsuda M, Handa H, Matsushima M, Ando K. Multiple meningiomas (report of four cases). $J \mathrm{Neu}$ rosurg 1972;37:348-51.

${ }^{24}$ Poisson M, Magdelenat H, Foncin JF, Bleibel JM, Philippon J, Pertuiset B, Buge A. Récepteurs d'oestrogenes et de progestérone dans les méningiomes. Rev Neurol (Paris) 1980;136:193-203.

${ }^{25}$ Markwalder T-M, Zava DT, Goldhirsch A, Markwalder $R$. Estrogen and progesterone receptors in meningiomas in relation to clinical and pathologic features. Surg Neurol 1983;20:42-47.

${ }^{26}$ Cahill DW, Bashirelahi N, Solomon LW, Dalton T, Salcman M, Ducker TB. Estrogen and progesterone receptors in meningiomas. $J$ Neurosurg 1984;60:985-93. 